\title{
Ballast Device
}

National Cancer Institute

\section{Source}

National Cancer Institute. Ballast Device. NCI Thesaurus. Code C49836.

An electrical device designed to limit an electric current or to provide a starting voltage. 